\title{
Microstructure Evolution of Novel Al-Cu-Li-Ce Alloys during Homogenization
}

\author{
Yu Xinxiang1, $\quad$ Yin Dengfeng ${ }^{1,2}, \quad$ Yu Zhiming ${ }^{1}, \quad$ Zhang Yiran $^{1}, \quad$ Li Shufei $^{1}$ \\ ${ }^{1} 2011$ Non-ferrous Metal Structural Materials and Advanced Manufacturing Collaborative Innovation Center, Central South University, \\ Changsha 410083, China; ${ }^{2}$ Yantai Nanshan University, Yantai 265713, China
}

\begin{abstract}
The present work is aimed to clarify the formation of the $\tau_{1}\left(\mathrm{Al}_{8} \mathrm{Cu}_{4} \mathrm{Ce}\right)$ phase and its formation mechanism in the high $\mathrm{Cu}$ content alloys with $\mathrm{Ce}$ addition, i.e high $\mathrm{Cu} / \mathrm{Li} \mathrm{Al-Cu}-\mathrm{Li}-\mathrm{Ce}$ alloys. The microstructure evolution of the alloy during the two-step homogenization annealing process was investigated. Results show that the coarse $\mathrm{Ag}+\mathrm{Mg}$ enriched $T_{\mathrm{B}}\left(\mathrm{Al}_{7} \mathrm{Cu}_{4} \mathrm{Li}\right)$ phase and the primary AlCuCe phase occur under solidification. Two types of the minor $\tau_{1}$ phases are formed after homogenization. It is concluded that the $\tau_{1}$ phase nucleation mechanism could involve either nucleation on an existing $\mathrm{T}_{\mathrm{B}}$ phase by Ce diffusion from the $\mathrm{Al}$ matrix or the transformation of the primary AlCuCe phase into the $\tau_{1}$ phase by Ce diffusion through the coarse primary AlCuCe phase shrink. It is deduced that the grain refinement is attributed to the primary $\mathrm{AlCuCe}$, which can promote $\alpha(\mathrm{Al})$ nucleation and further prohibit the grain growth for the experimental alloy.
\end{abstract}

Key words: novel $\mathrm{Al}-\mathrm{Cu}-\mathrm{Li}$ alloy; cerium element; segregation; $\tau_{1}$ phase; homogenization

Al-Li alloys have received considerable interest because of their attractive high strength to weight ratio, large elastic modulus, small anisotropy, excellent resistivity to damage and good weldability. These characteristics make the alloys a very attractive choice in all weight-critical applications ${ }^{[1,2]}$. In past several decades, a number of researchers have paid attention to the microstructure and the mechanical properties of $\mathrm{Al}-\mathrm{Cu}-\mathrm{Li}$ alloys with a trace amount of $\mathrm{Ag}, \mathrm{Mg}$ and $\mathrm{Zr}^{[3-7]}$.

The mechanical properties of the Al-Li-Mg alloys were improved and the negative effect of impurity $\mathrm{Fe}$ was controlled by $\mathrm{Ce}$ addition. The $\mathrm{Ce}$ addition was also reported to affect the ductility and the fracture toughness of 8090 alloy sheets rich in impurities of $\mathrm{Fe}, \mathrm{Si}$ and alkali metals ${ }^{[8]}$. Once the $\mathrm{Cu}$ level is up to $5.8 \%$ in the present alloy system, an isothermal section of $\mathrm{Al}-\mathrm{Cu}-\mathrm{Ce}$ ternary system phase diagram ${ }^{[9]}$ must be taken into consideration and the $\mathrm{Ce}$ containing precipitates observed in such a system might be $\tau_{1}\left(\mathrm{Al}_{8} \mathrm{Cu}_{4} \mathrm{Ce}\right)$ phase. Ce addition in the $\mathrm{Al}$ alloys usually has following three effects: (i) hindering the diffusion of the major elements in experimental alloys and finally retarding the coarsening of primary strengthening phases, e.g. Xiao found that the addition of Ce up to $0.45 \mathrm{wt} \%$ improved the thermal stability of the $\Omega$ phase in $\mathrm{Al}-\mathrm{Cu}-\mathrm{Mg}-\mathrm{Ag}$ base alloys ${ }^{[8]}$. (ii) forming primary $\mathrm{AlCuCe}$ phase which acted as nucleating agents for remainder liquid solidified to $\alpha(\mathrm{Al})$ and combined with $\mathrm{Ce}$ atoms to segregate at the solidification front of the dendrites so as to increase the region of compositional supercooling and finally reduce the arm spacing of secondary dendrites ${ }^{[10]}$, e.g. grain size varied with the $\mathrm{Ce}$ content in $\mathrm{Al}-\mathrm{Cu}-\mathrm{Mg}-\mathrm{Mn}-\mathrm{Ag}$ alloys ${ }^{[11]}$ and the dendritic structure could be refined, the morphology of precipitates changed from spherical to needle shape when Ce content varied from $0.1 \%$ to $0.4 \%$ (mass fraction) in $7055 \mathrm{Al}$ alloy ${ }^{[12]}$. In addition, J. P. Lai et al. ${ }^{[13]}$ also found that addition of Ce could remarkably refine the as cast grains and eutectic microstructure. (iii) forming $\tau_{1}$ dispersoids during homogenization and thermal mechanical process. These types of particles played a high antirecrystallized effectiveness in the alloy during following heat treatment ${ }^{[14]}$. 
The aim of the present study is to investigate the feature of the microstructure evolution and the possibility of the formation of the $\tau_{1}$ phase in the Ce-added novel $\mathrm{Al}-\mathrm{Cu}-\mathrm{Li}$ complex alloy system during homogenization.

\section{Experiment}

The alloy with a chemical composition of Al-2.46Cu-5.08Li $-0.054 \mathrm{Ce}-0.1 \mathrm{Ag}-0.45 \mathrm{Mg}-0.04 \mathrm{Zr}$ (at\%) was prepared. Master alloys of $\mathrm{Al}-\mathrm{Zr}, \mathrm{Al}-\mathrm{Ce}$ and $\mathrm{Al}-\mathrm{Cu}$ and pure elements of $\mathrm{Ag}, \mathrm{Mg}$, $\mathrm{Li}$ and $\mathrm{Al}$ were melted in a vacuum induction melting furnace under a controlled atmosphere of argon gas, using high pure graphite crucible. Lithium addition was made by plunging $\mathrm{Li}$ wrapped in aluminium foil. Casting was carried out under $\operatorname{argon}^{[15]}$. The ingot was homogenized using two-step homogenization cycle at $470{ }^{\circ} \mathrm{C}, 8 \mathrm{~h}+510{ }^{\circ} \mathrm{C}, 16 \mathrm{~h}$ in a salt bath.

Specimens cut from the ingot as-cast and homogenized were observed by optical and electronic microscope. Grain structure of the specimens was determined after being anodized with Barker's reagent $\left(1.8 \% \mathrm{HBF}_{4}\right.$ solution with a voltage of $20 \sim 30 \mathrm{~V}$ and a current of $0.5 \sim 1.5 \mathrm{~mA}$ ) and viewed with cross-polarized light on Leica DMILM optical microscope $(\mathrm{OM})$. Phase analysis was performed with X-ray diffractometer (XRD, Rigaku D/ $\max 2500$ ). A Quanta-200 environmental scanning electron microscope (SEM) was used for the evaluation of the microstructural features of the alloy. The wave length-dispersive X-ray spectrometer (WDS) microanalysis of the intermediate phases in arbitrarily selected area was performed on JEOL JXA-8230 electron microprobe analysis (EPMA) instrument. In addition, differential scanning calorimeter (DSC) analysis of specimens by NETZSCH STA 449C was carried out under argon atmosphere to analyze the transition of phases during the homogenization treatment.

\section{Results}

\subsection{Microstructure observation}

Optical micrographs of the grain structures of the alloy are presented in Fig.1. The alloy in as-cast condition consists of typical large and dendritic grains. The average grain size is 200 300 $\mu \mathrm{m}$, and the dendrite arm spacing (DAS) is $\sim 30 \mu \mathrm{m}$ (Fig.1a). Compared to other Al-Cu-Li alloy, e.g. 1469 Al-CuLi-Sc (grain size 400 500 $\mu \mathrm{m})^{[16]}$ and Al-Cu-Li-Mn-Zr-Ti alloy (DAS 80 100 $\mu \mathrm{m})^{[17]}$, the remarkable refinement of the columnar grains containing the dendritic substructure with complex alloying by $\mathrm{Ce}$ and $\mathrm{Zr}$ is observed; DAS is reduced simultaneously. A great degree of dendritic microsegregation exists within the grains. After homogenization, the dentritic grain structure is eliminated basically, as shown in Fig.1b. The grain boundaries become level and smooth.

Fig.2 shows the SEM images for the solidification and homogenization microstructure of the alloy. Coarse continuous non-equilibrium phases are distributed both within the interiors of dendrite cells and on the dendrite boundaries that
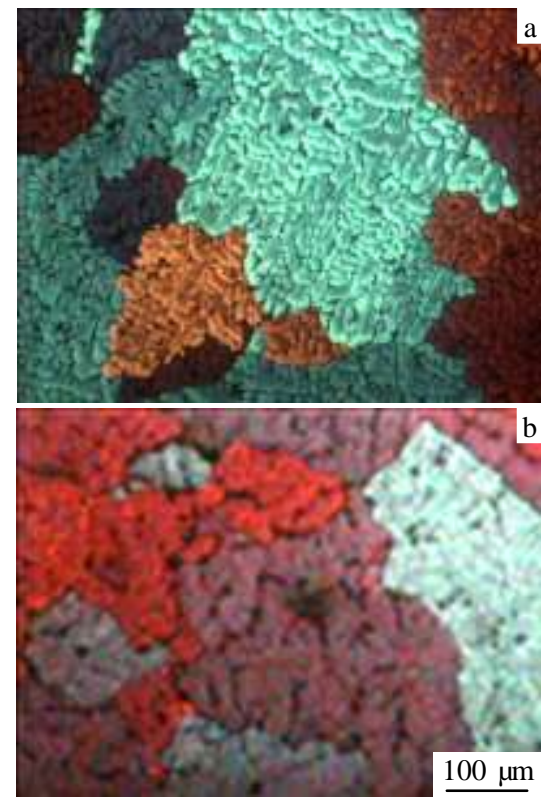

Fig.1 OM images of the experimental alloy with cross polarized light: (a) as-cast and (b) homogenized

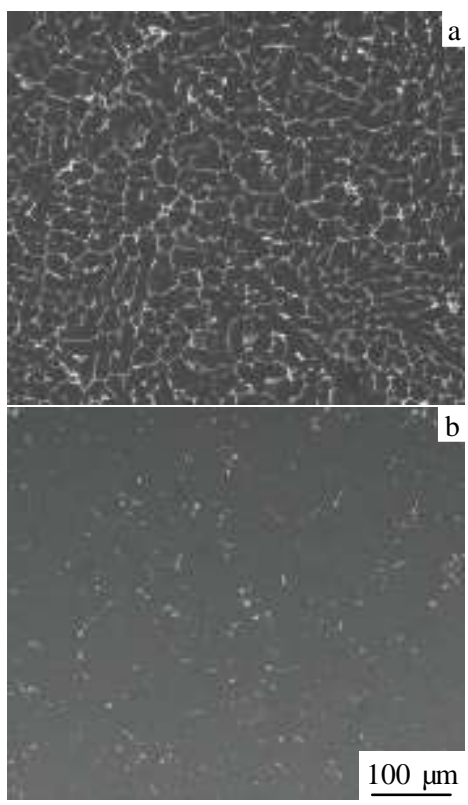

Fig.2 Backscattered SEM images of the experimental alloy: (a) as-cast and (b) homogenized

comprise the shell, as the white net-like parts shown in Fig.2a. However, in the homogenized structure, vast arrays of discontinuous small particles are visible instead of those coarse continuous phases, as shown in Fig.2b. This indicates that most of the continuous non-equilibrium phases are dissolved and some other phases are formed.

\subsection{Segregation of the alloying elements before and after homogenization}

Fig. 3 is the SEM images and the elements mappings of the 


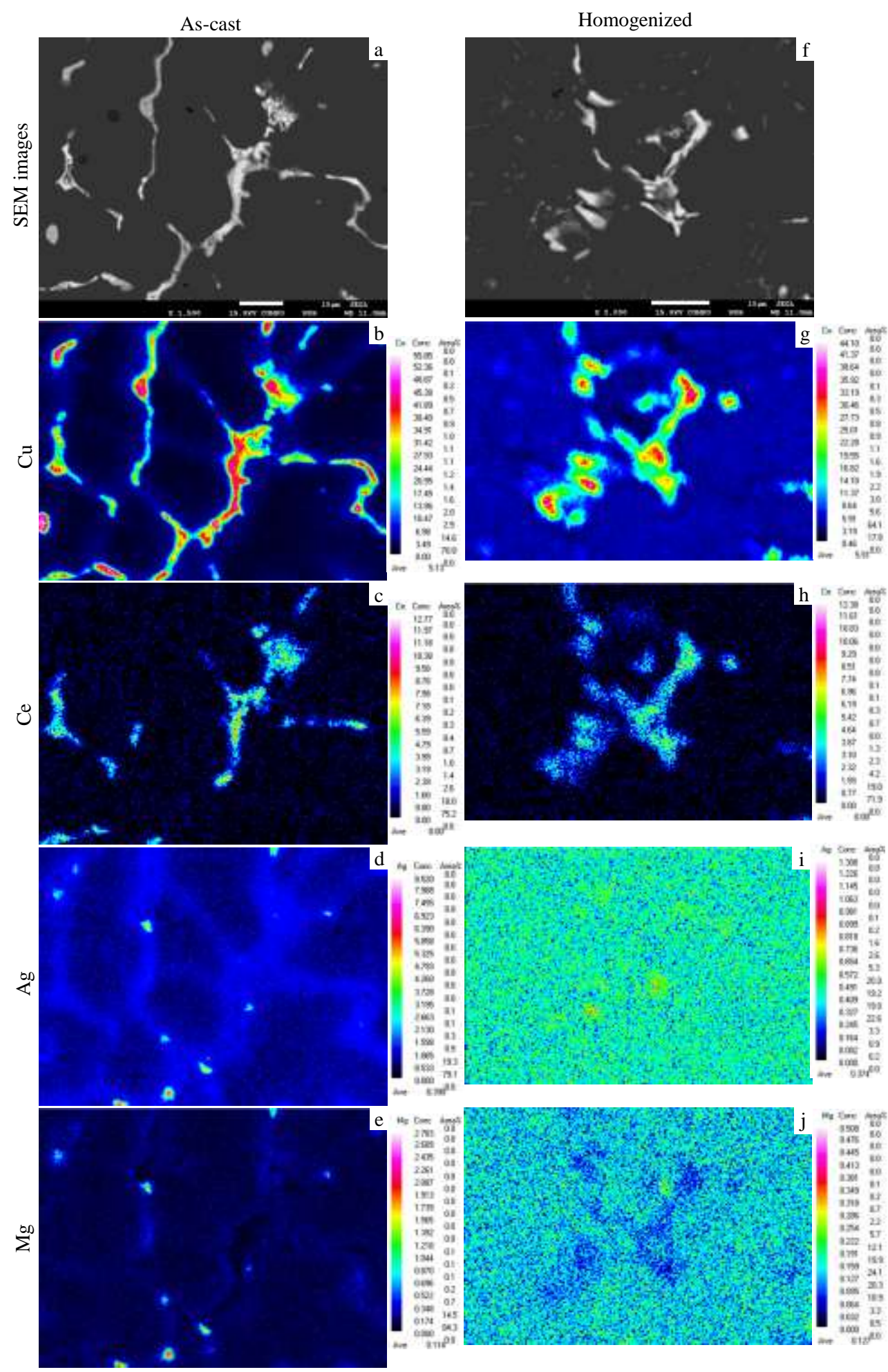

Fig.3 Elements map-scanning of the selected region in the as-cast structure and homogenized structure: (a, f) SEM images, (b, g) Cu, (c, h) Ce, (d, i) Ag, and (e, j) Mg

studied alloy by EPMA. $\mathrm{Cu}$ atoms are distributed within the coarse continuous phases entirely, and a few of Ce segregate at the area with $\mathrm{Cu}$ enrichment. The $\mathrm{Mg}$ and $\mathrm{Ag}$ tend to be concentrated together at the localized region of these continuous phases. After homogenization, $\mathrm{Ce}$ and $\mathrm{Cu}$ further gather together in the $\mathrm{Cu}$-rich area intensely. The segregation of $\mathrm{Mg}$ and $\mathrm{Ag}$ are eliminated considerably and they become uniformly distributed within grains, which indicate that the homogenization treatment has successfully eliminated the microsegregation of $\mathrm{Mg}$ and $\mathrm{Ag}$. 
Fig.3b and Fig.3g show the distribution of $\mathrm{Cu}$ before and after homogenization, respectively. It is obvious that the $\mathrm{Cu}$ atoms segregate more strongly in the continuous phases formed during solidification. Correspondingly, the $\mathrm{Cu}$ atoms fixed in the Al matrix of the solidification microstructure are relatively deficient. The color of the $\mathrm{Al}$ matrix showing deep dark confirms this (Fig.3b). The Al matrix becomes light colored after homogenization, showing blue (Fig.3g), which means that the $\mathrm{Cu}$ content in the matrix rises. The results suggest that $\mathrm{Cu}$ atoms tend to move from the coarse continuous phases towards the $\mathrm{Al}$ matrix during homogenization annealing. In contrast, the distribution of $\mathrm{Ce}$ shown in Fig.2c indicates that the degree of Ce segregation in the array of the "skeleton" particles formed after homogenization is seen to be higher. This observation will be confirmed by the further quantified analysis in the following section.

\subsection{Phase constitution}

Fig. 4 shows the XRD patterns of the alloy both in the as-cast and the homogenized states. It can be observed that as-cast alloy is mainly composed of $\alpha(\mathrm{Al})$ solid solution, $T_{\mathrm{B}}\left(\mathrm{Al}_{7} \mathrm{Cu}_{4} \mathrm{Li}\right)$ and $\tau_{1}\left(\mathrm{Al}_{8} \mathrm{Cu}_{4} \mathrm{Ce}\right)$ (serve as primary $\mathrm{AlCuCe}$ phase in the present work due to relatively low Ce content compared to $\tau_{1}$ particle formed during homogenization) phases. After homogenization of the experimental alloy, there are no obvious diffraction peaks of $T_{\mathrm{B}}$ phases. This indicates that the majority of $T_{\mathrm{B}}$ phase formed during the solidification process has dissolved back to Al matrix. However, XRD peaks originating from the $\tau_{1}$ phase are distinguished both in the as-cast and the homogenized states.

The SEM image of solidification microstructure (Fig.5a) shows that the coarse continuous particle can be divided into two types of phases because of well-defined differences in their morphology and brightness. The WDS analyses of point 1 in the brighter and thinner part of continuous phase ("skeleton" phase), point 2 in the normal part of continuous phase and point 3 in the matrix are listed in Table1. The contents of $\mathrm{Mg}$ and $\mathrm{Ag}$ are 0.2148 at\% and 0.0627 at\%, respectively, in the point 1 and the Ce level is measured to be 2.1281 at $\%$. Compared to point 1, the content of $\mathrm{Mg}$ and $\mathrm{Ag}$ are found to be double more in the point 2 , while its Ce level is

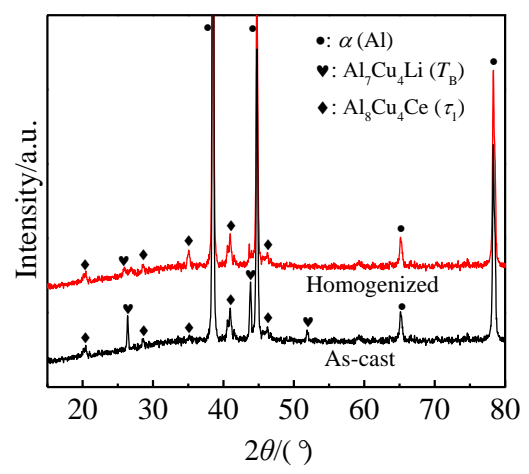

Fig.4 XRD patterns of the experimental alloy

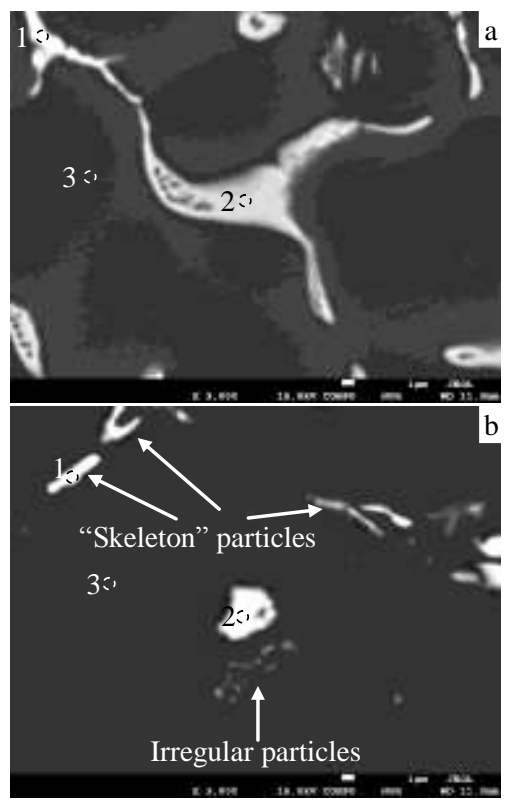

Fig.5 Backscattered SEM images of the experimental alloy: (a) as-cast and (b) homogenized

relatively low. Furthermore, the composition profiles along the line across the two types of coarse phase are indicated in Fig.6a. It is easily observed that $\mathrm{Ce}$ is only detected in the brighter part of continuous phase. However, the contents of $\mathrm{Mg}$ and $\mathrm{Ag}$ start to rise for the phase without $\mathrm{Ce}$ in the normal part of continuous phase.

The typical phases of the alloy after homogenization are the "skeleton" particles and the discontinuous irregular particles (Fig.2d). The SEM image of the phase is shown in Fig.5b. The variation of the components along line across the two types of particles is shown in Fig.6b. Table 2 shows the WDS composition analysis of point 1 in "skeleton" particles, point 2 in irregular particles and point 3 in matrix. Two types of discontinuous particles contain mainly $\mathrm{Al}, \mathrm{Cu}$ and $\mathrm{Ce}$, of which the content of Ce reaches 5.4110at\% and 4.1541at\%, respectively. In addition, it is clearly observed that $\mathrm{Mg}$ content is decreased largely in Ce enrichment area.

A comparison of the compositions of the predominant second phases (particle 1 shown in Fig.5) as well as the matrix before and after homogenization in Table 1 and Table 2 is obtained. It reveals that higher level of $\mathrm{Ce}$ is found within the second phase after homogenization. It also presents that the content of Ce fixed in the matrix decreases from 0.0207 at $\%$ to 0.0113 at\%, while the content of $\mathrm{Cu}$ increases from 1.4555 at $\%$ to 1.7505 at $\%$ after the homogenization annealing. The results are in accordance with those in Fig.3, which indicate that a considerable amount of $\mathrm{Cu}$ dissolve into the matrix and parts of Ce diffuse from matrix to the Ag-Mg enrichment phase to form the $\tau_{1}$ phase.

\subsection{Microstructure evolution during homogenization annealing}

Fig.7 shows the SEM images of microstructures of the alloy 

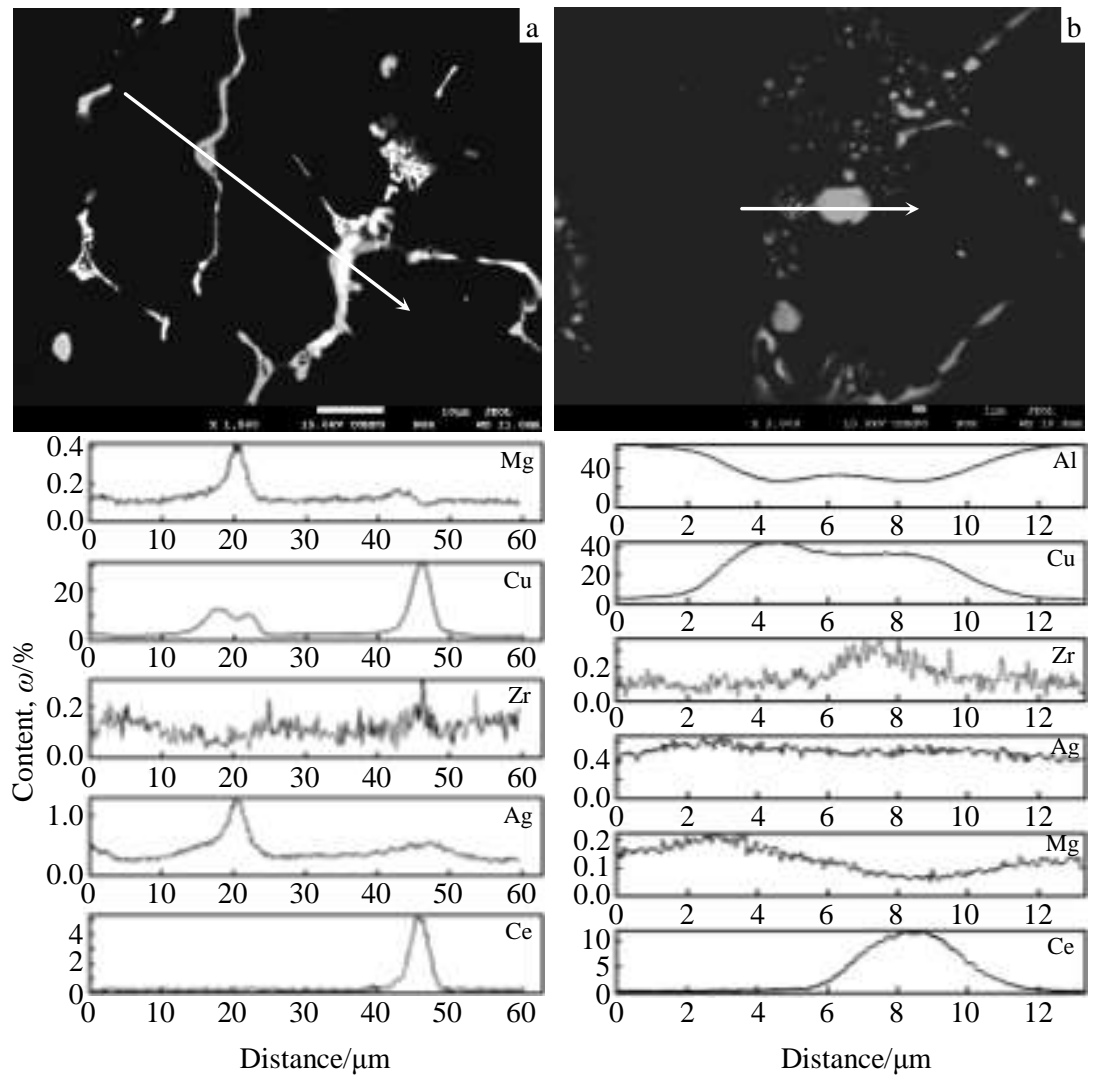

Fig.6 Backscattered SEM images and elements line-scanning across the coarse phase as the lines with arrows in upper pictures:

(a) as-cast and (b) homogenized

Table 1 WDS analysis of the as-cast experimental alloy in Fig.5a (at\%)

\begin{tabular}{cccccccccc}
\hline Point & $\mathrm{Al}$ & $\mathrm{Cu}$ & $\mathrm{Ag}$ & $\mathrm{Mg}$ & $\mathrm{Zr}$ & $\mathrm{Fe}$ & $\mathrm{Si}$ & $\mathrm{Ce}$ & Total \\
\hline 1 & 74.2398 & 22.9415 & 0.0627 & 0.2148 & 0.1668 & 0.1923 & 0.0529 & 2.1281 & 100.0000 \\
2 & 76.4389 & 22.1606 & 0.1254 & 0.5621 & - & 0.7030 & 0.0496 & 0.0100 & 100.0000 \\
3 & 98.3532 & 1.4555 & 0.0621 & 0.0799 & 0.0226 & 0.0059 & 0.0119 & 0.0207 & 100.0000 \\
\hline
\end{tabular}

Table 2 WDS analysis of the homogenized experimental alloy in Fig.5b (at\%)

\begin{tabular}{cccccccccc}
\hline Point & $\mathrm{Al}$ & $\mathrm{Cu}$ & $\mathrm{Ag}$ & $\mathrm{Mg}$ & $\mathrm{Zr}$ & $\mathrm{Fe}$ & $\mathrm{Si}$ & $\mathrm{Ce}$ & Total \\
\hline 1 & 62.6571 & 31.4556 & 0.0341 & 0.0566 & 0.1962 & 0.1454 & 0.0440 & 5.4110 & 100.0000 \\
2 & 63.8824 & 30.5728 & 0.0834 & 0.0673 & 0.2810 & 0.9111 & 0.0479 & 4.1541 & 100.0000 \\
3 & 97.997 & 1.7505 & 0.0799 & 0.0916 & 0.0450 & 0.0030 & 0.0217 & 0.0113 & 100.0000 \\
\hline
\end{tabular}

homogenized for different time. Fig.7a shows the features of the as-cast structure. The white coarse particles appear to be complete and continuous. As shown in Fig.7b, upon heating at $470{ }^{\circ} \mathrm{C}$ for $8 \mathrm{~h}$, the whole profile of the primary $\mathrm{AlCuCe}$ phase barely changes (as arrows pointed). On the other hand, the majority of the $\mathrm{Ag}+\mathrm{Mg}$ enriched $T_{\mathrm{B}}$ phase begins to dissolve and shrink. Fig.7c shows the typical feature of the microstructure of the alloy after homogenizing at $470{ }^{\circ} \mathrm{C}$ for 8 $\mathrm{h}$ followed by a high temperature step at $510^{\circ} \mathrm{C}$ for $8 \mathrm{~h}$. The majority of the coarse $T_{\mathrm{B}}$ phase disappears and the elongated parts of primary $\mathrm{AlCuCe}$ phase have already broken off (as arrows pointed). Fig.7d shows the microstructure of the alloy after homogenizing at $470{ }^{\circ} \mathrm{C}$ for $8 \mathrm{~h}$ followed by heating at
$510{ }^{\circ} \mathrm{C}$ for $16 \mathrm{~h}$. The volume of the second phase diminishes further and the array of the discontinuous particles is initially formed. There are two $\tau_{1}$ phases formed during homogenization in Fig.7d. One is transformation from the primary $\mathrm{AlCuCe}$ phase into the rodlike (as circle pointed) and the other is nucleation on an existing $T_{\mathrm{B}}$ phase which converts into $\tau_{1}$ phase (remainder minor white particle). At the same time, $T_{\mathrm{B}}$ phase cannot be seen in the alloy any more.

\subsection{DSC analysis}

Fig.8 shows DSC plots for the alloy in both the as-cast and the homogenized states. A well-defined difference is evident in the precipitation behavior between the two states of the Al-Cu-Li-Ce alloy. At 518 and $599{ }^{\circ} \mathrm{C}$, a double endothermic 
peak appears in the alloy after solidification, and the homogenized alloy exhibits an almost-single, distinct endothermic peak at $599{ }^{\circ} \mathrm{C}$. At $518{ }^{\circ} \mathrm{C}$, the endothermic peak is largely caused by the dissolution reaction of low melting phase ( $T_{\mathrm{B}}$ phase), which is similar to general $\mathrm{Al}-\mathrm{Cu}$ alloy where the DSC endothermic peak at $532{ }^{\circ} \mathrm{C}$, is largely caused by the melting of the $\mathrm{Al}_{2} \mathrm{Cu}$ phase ${ }^{[18,19]}$. A decrease in the volume fraction of the $T_{\mathrm{B}}$ phase after homogenization annealing leads to a significant decrease in the intensity of this peak up to a negligible value. For the alloy in the as-cast state, the DSC curve tends to be endothermic, which indicates the gradual dissolution of the $T_{\mathrm{B}}$ phase with heating. In contrast, for the alloy in the homogenizing state, the DSC curve provides weak evidence for the gradual dissolution of the $T_{\mathrm{B}}$ phase. Therefore, homogenization annealing eliminates massive melting at $518{ }^{\circ} \mathrm{C}$.

The endothermic peak at $599{ }^{\circ} \mathrm{C}$ is attributed to the partial melting of other high-temperature phases. The homogenization annealing obviously increases the intensity of this peak. The Ce containing $\tau_{1}$ phase is mainly responsible for this peak.

\section{Discussion}

The modification of the cast structure with $\mathrm{Sc}$ addition was attributed to the formation of the primary $\mathrm{Al}_{3} \mathrm{Sc}$ during solidification ${ }^{[20-22]}$. The primary $\mathrm{Al}_{3} \mathrm{Sc}$ precipitates could be formed prior to the solidification of the aluminum phase and act as nuclei of solidifying aluminium grains ${ }^{[23]}$. Analogously, when the Ce content is 0.054 at\%, the present experimental alloy owns a primary $\mathrm{AlCuCe}$ phase which acts as nucleating agents for remainder liquid solidified to $\alpha(\mathrm{Al})$ continually at $590{ }^{\circ} \mathrm{C}^{[9]}$. Therefore the grain size and the typical dentritic grain structure of the studied high $\mathrm{Cu} / \mathrm{Li} \mathrm{Al}-\mathrm{Cu}-\mathrm{Li}$ as-cast alloy manifest that the $\mathrm{Ce}$ addition can refine the cast structure considerably (Fig.1a).

An inspection of the experimental result after homogenization shows that the Ce additives do not lead to unusual $\mathrm{Ag}$ or $\mathrm{Mg}$ segregation; therefore, this additional alloying will not affect the size and distribution of the $T_{1}$ phase precipitating during artificial ageing ${ }^{[24]}$. However, $\mathrm{Ag}+\mathrm{Mg}$ enriched $T_{\mathrm{B}}$ phase is observed in as-cast experimental alloy, which is attributed to and consistent with the strong attraction between $\mathrm{Ag}$ and $\mathrm{Mg}$ owing to the large difference in electronegativity between them, i.e. 0.7 , together with the fact that $\mathrm{Ag}$ reduces the solubility of $\mathrm{Mg}$ in $\mathrm{Al}^{[25]}$.

According to the SEM observations, it is concluded that the $\tau_{1}$ phase nucleation mechanism could involve either nucleation on an existing $\mathrm{Mg}+\mathrm{Ag}$-rich $T_{\mathrm{B}}$ phase (Fig.9 upper) or the transformation of the primary $\mathrm{AlCuCe}$ phase particle into the $\tau_{1}$ phase by Ce diffusion mainly from some part of the primary $\mathrm{AlCuCe}$ phase into $\mathrm{AlCuCe}$ remain part (Fig.9 bottom). In the case of nucleation on the $T_{\mathrm{B}}$ phase, the $\tau_{1}$ phase constituents $(\mathrm{Ce}$ and $\mathrm{Cu}$ ) must be present in the $\mathrm{Al}$ matrix to form a nucleus at the $T_{\mathrm{B}}$ phase/Al interface. This interface represents a preferred nucleation site because the incoherent interface with the $T_{\mathrm{B}}$ phase reduces the interfacial energy. After the $\tau_{1}$ phase is nucleated, it will grow by consuming the $T_{\mathrm{B}}$ phase particle next to it and also by diffusion of Ce through the Al matrix fixed within the supersaturated solid solution. In the case of the transformation mechanism, Ce diffuses into the

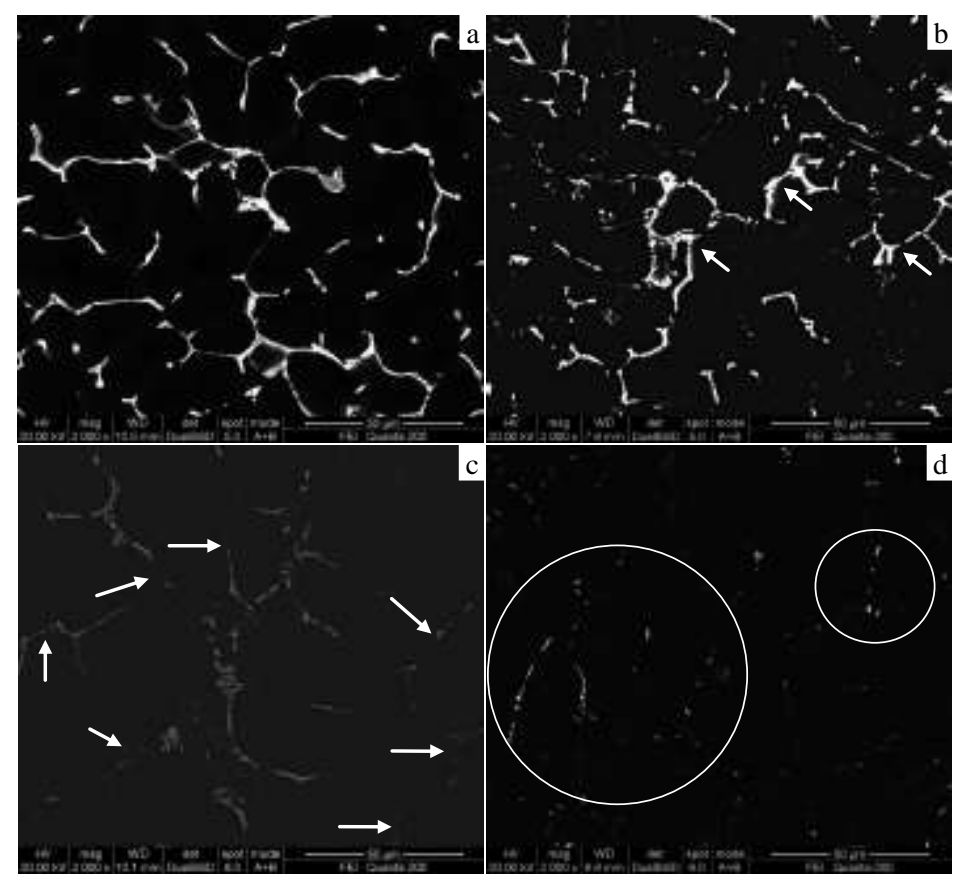

Fig.7 SEM images of the typical microstructures at the different stages of homogenization: (a) as cast; (b) $470{ }^{\circ} \mathrm{C}, 8 \mathrm{~h}$; (c) $470{ }^{\circ} \mathrm{C}, 8 \mathrm{~h}+510{ }^{\circ} \mathrm{C}, 8 \mathrm{~h}$; (d) $470{ }^{\circ} \mathrm{C}, 8 \mathrm{~h}+510{ }^{\circ} \mathrm{C}, 16 \mathrm{~h}$ 


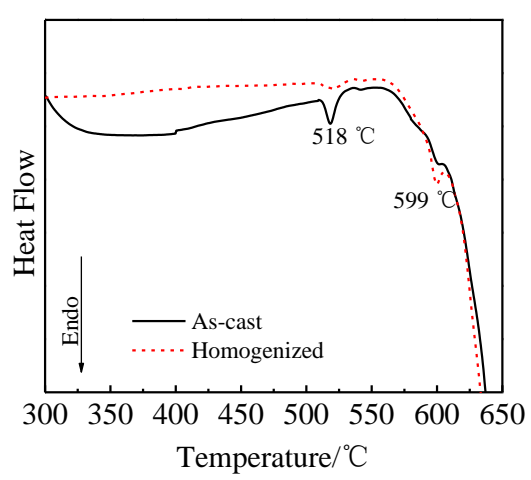

Fig.8 DSC curves for the alloy before and after homogenization annealing

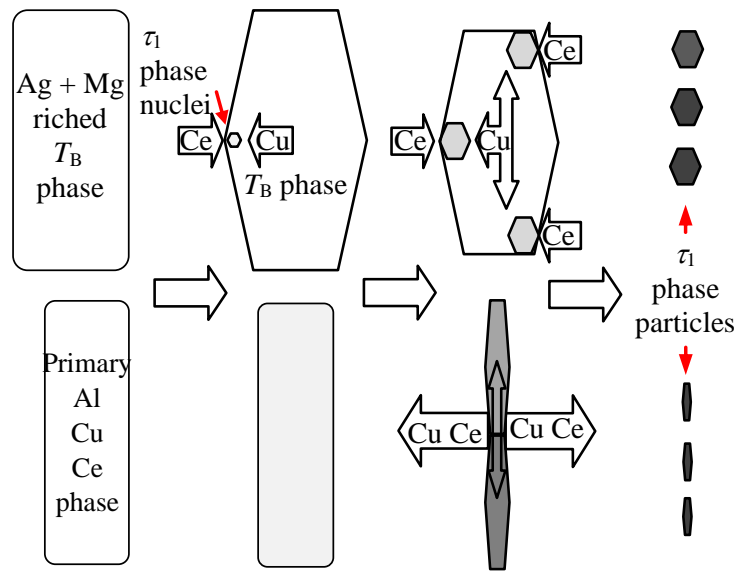

Fig.9 Schematic diagrams of formation of $\tau_{1}$ phase during homogenization

primary $\mathrm{AlCuCe}$ phase particle itself, which increases the $\mathrm{Ce}$ content (at\%) by a factor of 2 or more.

\section{Conclusions}

1) The grain sizes can be significantly refined with addition of rare earth $\mathrm{Ce}$.

2) The addition of Ce into the Al-Cu-Li alloy leads to the formation of the $\tau_{1}$ phase. The primary $\mathrm{AlCuCe}$ phase is formed in the as-cast structure. Under homogenization annealing, the coarse primary $\mathrm{AlCuCe}$ phase shrinks, breaks off during homogenization and transforms into the $\tau_{1}$ phase ultimately; on the other hand, the $\mathrm{Mg}+\mathrm{Ag}$ rich $T_{\mathrm{B}}$ phase dissolves and the $\tau_{1}$ phase forms.

\section{References}

1 Araullo-Peters V, Gault B, DeGeuser F et al. Acta Materialia[J],
2014, 66: 199

2 Nayan N, Murty N, Jha A K et al. Materials Science and Engineering $A[\mathrm{~J}], 2013,576: 21$

3 Yu Xinxiang, Yu Zhiming, Ying Dengfeng et al. Rare Metal Materials and Engineering[J], 2014, 43(2): 495 (in Chinese)

4 Kumar K S, Heubaum F H. Acta Materialia[J], 1996, 45: 2317

5 Itoh G, Cui Q, Kanno M. Materials Science and Engineering A[J], 1996, 211: 128

6 Pan Z R, Zheng Z Q, Liao Z Q. Materials Letters[J], 2010, 64: 942

7 Gault B, Geuser F D, Bourgeois L. Ultramicroscopy[J], 2011, 111: 207

8 Xiao D H, Wang J N, Ding D Y et al. Journal of Alloys and Compounds [J], 2003, 352: 84

9 Bo H, Jin S, Zhang L G et al. Journal of Alloys and Compounds [J], 2009, 484: 286

10 Si N C, Guo Y, Li G Q et al. The Chinese Journal of Nonferrous Metals[J], 2006, 16 (4): 606 (in Chinese)

11 Chen K H, Fang H C, Zhang Z et al. Materials Science Forum[J], 2007, 546: 1021

12 Chaubey A K, Mohapatra S, Jayasankar K et al. Transactions of the Indian Institute of Metals[J], 2009, 62(6): 539

13 Lai J P, Jiang R P, Liu H S et al. Journal of Central South University[J], 2012, 19(4): 869

14 Zakharov V. Metal Science and Heat Treatment[J], 2012, 53: 414

15 Yu Xinxiang, Yin Dengfeng, Yu Zhiming et al. Rare Metal Materials and Engineering[J], 2014, 43(5): 1061 (in Chinese)

16 Jia M, Zheng Z Q, Gong Z. Journal of Alloys and Compounds[J], 2014, 614: 131

17 Li H Y, Su X J, Yin H et al. Transactions of Nonferrous Metals Society of China[J], 2013, 23(9): 2543

18 Liu X Y, Pan Q L, Fan X et al. Journal of Alloys and Compounds [J], 2009, 484: 790

19 Ma F, Liu Z. International Journal of Modern Physics[J], 2009, 23: 855

20 Yin Z, Pan Q, Zhang Y et al. Materials Science and Engineering $A[\mathrm{~J}], 2000,280: 151$

21 Norman A, Prangnell P, McEwen R. Acta Materialia[J], 1998, 46: 5715

22 Zakharov V. Metal Science and Heat Treatment[J], 2003, 45: 246

23 Singh V, Satya Prasad K, Gokhale A A. Scripta Materialia[J], 2004, 50: 903

24 Huang B P, Zheng Z Q. Acta Materialia[J], 1998, 46(12): 4381

25 Mukhopadhyay A K, Rama Rao V V. Materials Science and Engineering $A[\mathrm{~J}], 1999,268: 8$ 


\title{
均匀化热处理对新型 Al-Cu-Li-Ce 合金的微观结构的影响
}

\author{
余金祥 ${ }^{1}$, 尹登峰 ${ }^{1,2}$, 余志明 ${ }^{1}$, 张亦然 ${ }^{1}$, 李树飞 ${ }^{1}$ \\ (1. 中南大学 2011 有色金属先进结构材料与制造协同创新中心，湖南 长沙 410083)
}

(2. 烟台南山学院, 山东 烟台 265713)

\begin{abstract}
摘 要: 研究了一种添加 $\mathrm{Ce}$ 并具有高 $\mathrm{Cu} / \mathrm{Li}$ 的新型 $\mathrm{Al}-\mathrm{Cu}-\mathrm{Li}-\mathrm{Ce}$ 合金在双极均匀化热处理过程中微观结构的演化过程, 并重点探讨了该 合金中 $\tau_{1}\left(\mathrm{Al}_{8} \mathrm{Cu} u_{4} \mathrm{Ce}\right)$ 相的形成过程及其形成机制。在凝固过程中 $\mathrm{Ag}, \mathrm{Mg}$ 富集的粗大的 $T_{\mathrm{B}}\left(\mathrm{Al}_{7} \mathrm{Cu} \mathrm{Cu}_{4} \mathrm{Li}\right)$ 相和原生的 $\mathrm{AlCuCe}$ 相共同形成。双 极均匀化热处理后有 2 种类型的 $\tau_{1}$ 相出现。该相的形成模式包括, 通过 $\mathrm{Ce}$ 不断的由 $\mathrm{Al}$ 基体向在 $T_{\mathrm{B}}$ 相上新形核的 $\tau_{1}$ 相扩散并导致该粒子不 断长大, 以及原生的 $\mathrm{AlCuCe}$ 相通过不断缩水并伴随 $\mathrm{Cu}, \mathrm{Ce}$ 向各个方向扩散, 由之转变为细小弥散的 $\tau_{1}$ 相。同时分析发现在合金凝固过程 中产生的这种先析 $\mathrm{AlCuCe}$ 相, 不但能够促进晶粒形核, 同时能够阻止晶粒进一步长大, 最终导致含铈的铸态合金晶粒得到细化。
\end{abstract}

关键词: 新型 $\mathrm{Al}-\mathrm{Cu}-\mathrm{Li}$ 合金; 铈; 偏聚; $\tau_{1}$ 相; 均匀化

作者简介: 余傘祥, 男, 1984 年生, 博士生, 中南大学材料科学与工程学院, 湖南 长沙 410083, 电话: 0731-88879341, E-mail: dfyin@126.com 